CATALLAXY

Volume 4 Issue 1 June 2019

e-ISSN 2544-090X

C www.catallaxy.pl

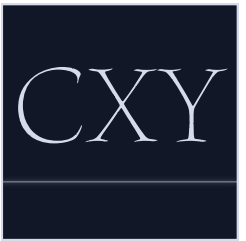

Oryginalny artykuł przeglądowy

otrzymano: 29.04.2019 / zaakceptowano: 28.06.2019 / opublikowano online: 30.06 .2019

Kaleta, M. (2019). Decyzje konsumentów a założenia ekonomii behawioralnej. Catallaxy, 4(1): 5-12. doi:10.24136/ cxy.2019.006.

\title{
Decyzje konsumentów a założenia ekonomii behawioralnej
}

\author{
MATEUSZ KALETA \\ Uniwersytet Mikotaja Kopernika w Toruniu, Wydziat Nauk Ekonomicznych i Zarzadzania, Katedra Gospodarowania \\ Zasobami Pracy, ul. Gagarina 13a, 87-100 Torú, Polska \\ \m.kaleta@doktorant.umk.pl \\ (D) orcid.org/0000-0002-9710-6252
}

\section{Abstrakt}

Motywacja: Kluczowym elementem wyborów dokonywanych przez konsumentów są aspekty psychologiczne. Ekonomia behawioralna staje się przez to jednym z najszybciej rozwijających się nurtów współczesnej ekonomii.

Cel: Celem artykułu przeglądowego jest wskazanie na najważniejsze związki, jakie istnieją między ekonomią a psychologią oraz przedstawienie założeń, które są kluczowe dla zrozumienia wyborów dokonywanych przez konsumentów na rynku.

Materiały i metody: Zastosowano metodę krytycznej analizy literatury przedmiotu oraz obserwację zachowań konsumentów.

Wyniki: Przeprowadzona analiza wskazuje na istnienie wieloaspektowych czynników, które mogą wpływać na decyzje podejmowane przez konsumentów i mieć konsekwencje dla gospodarstw domowych i ich członków.

Stowa kluczowe: ekonomia behawioralna; teoria wyboru konsumenta; psychologia; działania marketingowe JEL: B21;D11;M31

\section{Wprowadzenie}

Ekonomia behawioralna w ostatnim czasie zyskuje na znaczeniu. Obecnie wydaje się, że jest to jeden $z$ najbardziej interesujących i niezwykle szybko rozwijających się nurtów we współczesnej ekonomii. W centralnym punkcie zainteresowania ekonomii behawioralnej znajduje się człowiek, który jest podmiotem szeroko rozumianego systemu społeczno-ekonomicznego. Ekonomia behawioralna wydaje się stać w opozycji do racjonalności wyborów ekonomicznych człowieka. Bardziej zwrócono uwagę na aspekty psychologiczne podejmowanych przez człowieka decyzji (w większym stopniu skoncentrowano się na rzeczywistych zachowaniach rynkowych konsumentów).

Celem niniejszego artykułu przeglądowego jest wskazanie na najważniejsze związki, jakie istnieją między ekonomią a psychologią oraz wskazanie na założenia będące kluczowe dla zrozumienia wyborów dokonywanych przez konsumentów na rynku. Na podstawie przeglądu wybranych pozycji literatury przedmiotu opisującej przeprowadzone już w tym zakresie badania, podjęto próbę zwięzłego wskazania i opisania zależności zachodzących między aspektami psychologicznymi a motywami decyzyjnymi konsumentów na rynku. W wyniku dynamicznego rozwoju ekonomii behawioralnej, powstaje kluczowe pytanie 
o to, jakie czynniki są istotne $\mathrm{w}$ dokonywanych przez konsumentów wyborach. Znając je i rozumiejąc można wpływać na dokonywane przez konsumentów wybory poprzez działania i określone zachowania marketingowe, kreować potrzeby nabywcze w społeczeństwie, a w ten sposób wpływać na gospodarkę.

W sekcji 2. dokonano przeglądu literatury przedmiotu. W sekcji 3. opisano wykorzystane materiały i metody. W sekcji 4. przedstawiono otrzymane wyniki, natomiast w sekcji 5. zawarto podsumowanie przeprowadzonej analizy.

\section{Przegląd literatury}

\subsection{Punkt wyjścia do badań nad ekonomią behawioralną}

Początkowo, ekonomię starano się ujmować bardziej jako naukę ścisłą niż społeczną. Postrzeganie ekonomii jako nauki ścisłej miało swoje uzasadnione podstawy. Od XX wieku szkoła neoklasyczna przeważała w głównym nurcie ekonomii (Sołek, 2010, s. 21). Wywodziła się ona $z$ prac powstałych jeszcze w XIX wieku, stworzonych m.in. przez A. Marshalla (2013). To właśnie te prace wpłynęły na postrzeganie ekonomii bardziej jako nauki ścisłej niż społecznej. Wszystkie prace, które zasadniczo powstały $\mathrm{w}$ tamtym czasie, nawolywały wręcz do odwrotu od psychologizmu w dziedzinie ekonomii. Włoski ekonomista V. Pareto głosił pogląd, że nauki ścisłe nie służą wyjaśnianiu fundamentalnych zasad („istoty rzeczy”), ale koncentrują swoją uwag na tłumaczeniu „zasad wtórnych". V. Pareto nie zajmowal się $w$ swoich analizach badaniem i poszukiwaniem miernika użyteczności, ale aktem wyboru, który oparty był na subiektywnych preferencjach (Camerer, 2006, ss. 185-190).

Podstawową tezą neoklasyczną była ta dotycząca decyzji podejmowanych przez jednostki. Według niej, jednostki postępują w sposób racjonalny. Decyzje te wynikają więc $z$ działania na podstawie pełnej $i$, co warto podkreślić, $w$ pełni doskonałej infor- macji, a człowiek posiada nieograniczone możliwości do przetwarzania posiadanych informacji. Zdaniem badaczy wywodzących się $z$ nurtu neoklasycznego i jego zwolenników, celem osób podejmujących decyzję jest maksymalizacja użyteczności lub maksymalizacja zysku (w zależności od charakteru decydenta). Podejmując decyzje, jednostki działają $\mathrm{w}$ wąsko pojmowanym własnym interesie i nie uwzględniają użyteczności innych podmiotów prowadzących działalność lub również podejmujących decyzje.

\subsection{Krytyka ekonomii neoklasycznej przestrzenią dla ekonomii behawioralnej}

Wydaje się, że u podstaw nurtu zakładającego pełną racjonalność jednostek, które dysponują pełnymi i doskonałymi informacjami leży paradoks. Wynika on $z$ faktu, że człowiek nigdy nie jest w stanie poznać w sposób doskonały otaczającej go rzeczywistości, a co za tym idzie wszelkie decyzje obarczone są prawdopodobieństwem jakiejś niepewności. Obraz decydenta przedstawiony w nurcie neoklasycznym nie odpowiada więc temu, czego człowiek doświadcza w swojej istocie w rzeczywistości. U podstaw takiego twierdzenia może leżeć stanowisko M. Friedmana (1953, ss. 3-10), który wyszedł z założenia, że nie można dokonywać weryfikacji teorii naukowych i poddawać ich ocenie ze względu na prawdziwość twierdzeń, które powstały na ich gruncie, ale należy dostrzegać ich przydatność pragmatyczną. Pojawiał się również zarzut, że standardowy model ekonomiczny nie może być uznany za koncepcję, która byłaby w stanie objaśnić wszystkie zachowania ekonomiczne ludzi. Wobec tego, na gruncie tej koncepcji nie można udzielić odpowiedzi na pytanie o to, dlaczego konsumenci tak silnie reagują na względne zmiany wartości (a nie procentowe) oraz dlaczego na użyteczność ma wpływ porównywanie się $z$ innymi osobami, które znajdują się $w$ danym momencie w podobnej sytuacji. Na podstawie zarzutów, które zdawały się podważać wspomnianą teorię ekonomii, powstała przestrzeń poszukiwań teorii alternatywnej, która byłaby w stanie wypełnić brakujące elementy ukła- 
danki ekonomicznej, które odnaleziono w teorii neoklasycznej.

W przypadku człowieka, jego osobowości, charakteru, emocji i popędów, które często nim kierują, modele matematyczne nie wystarczą. Nie można zamknąć $\mathrm{w}$ nawet najdoskonalszych modelach matematycznych czy statystycznych nieprzewidywalnej ludzkiej natury (Zygan, 2013, s. 11). Stąd założenia neoklasyczne, przykładowo w kwestii podejmowania przez człowieka decyzji, wydają się być nieracjonalne.

O niewątpliwym wpływie emocji oraz uczciwości czy awersji do strat ponoszonych poprzez podjęcie przez człowieka konkretnych decyzji pisał również A. Smith w swojej publikacji zatytułowanej Teoria uczuć moralnych w 1759 roku (Próchnicki, 2006, s. 128). Jego następcy dążyli potem do rozwijania tej myśli.

J.M. Clark (1918, ss. 9-15), podkreślał potrzebę uwzględniania przez ekonomistów natury ludzkiej. W tym aspekcie, z pomocą $z$ pewnością przychodzi psychologia. Przewidywał, że dla części ekonomistów może być to niezwykle trudne do pogodzenia, ale twierdzil, że jeśli nie chcą oni korzystać z osiągnięć nauki, jaką jest psychologia, to muszą tworzyć własną psychologię, która jak to określił „będzie marną psychologią̧. Matematyka, wyliczenia, dane statystyczne dostarczają człowiekowi narzędzi, które mogą być pomocne w podejmowaniu decyzji dotyczącej np. wyboru określonej opcji. Dokonanie takiej analizy pozwala człowiekowi również na określenie ewentualnych strat, które mogą nastąpić $w$ wyniku podjęcia określonych działań czy decyzji. Nie dadzą mu jednak odpowiedzi na pytania dotyczące siły woli pragnienia podjęcia tej decyzji, nawet jeśli w perspektywie jest poniesienie jakiejś straty.

H. Simon, w 1978 roku przedstawił własną propozycję postrzegania koncepcji racjonalności. Krytykując wspomnianą teorię racjonalnego podejmowania decyzji (za którą tak usilnie obstawali neoklasycy), stwierdził, że na gruncie nauk ekonomicznych oraz analizując naturę człowieka można stwierdzić ograniczoną racjonalność $\mathrm{w}$ podejmowaniu decyzji (Bogdanowicz, 2014, s. 26). Co istotne, $\mathrm{w}$ koncepcji zaproponowanej przez H. Simona, decydenci dysponują niepelną informacją oraz posiadają ograniczone możliwości jej przetwarzania. H. Simon (1982) podkreślał, że jednostki nie są w stanie dokonywać maksymalizacji funkcji celu, a poziom ich zadowolenia jest tożsamy $z$ osiągnięciem wystarczającego poziomu użyteczności. Takiego, który będzie dla jednostki satysfakcjonującym. Jako ciekawostkę, warto przywołać również inny wniosek wyciągnięty przez tego badacza, $z$ obserwacji jakie przeprowadził. Uważał on, że jednostki decydują się na pewne rozwiązania, które niekoniecznie są w stanie zapewnić im maksymalizację poziomu użyteczności lub największe zyski, ale na takie, które potrafią zapewnić osiągnięcie innych celów, które jednostka stawia sobie za najistotniejsze z punktu widzenia jej hierarchii wartości. Tymi wartościami mogą być m.in. satysfakcja, szczęście oraz rodzina.

D. Kahneman i A. Tversky (1986, ss. 253260) przedstawili tzw. teorię perspektywy. $Z$ racji posiadanego przez nich wykształcenia psychologicznego, włączyli oni wyniki badań i obserwacji psychologicznych do nauk ekonomicznych. Położyli oni głównie nacisk na funkcjonowanie umysłu człowieka i podejmowane przez niego osądy w warunkach ryzyka. Według nich, ludzie podejmują decyzje dążąc do efektywnego osiągnięcia swoich celów, co więcej, robią to w sposób masowy. W ich ocenie, tylko wtedy możliwa do wykorzystania staje się normatywna analiza tych zachowań. Istotny staje się również opis podejmowanych poprzez poszczególne jednostki decyzji jako procesów dążenia do maksymalizacji korzyści. Teoria perspektywy stała się jedną z najważniejszych koncepcji, które zostały opracowane na gruncie ekonomii behawioralnej. Pojawiła się ona $w$ miejsce funkcji użyteczności majątku, określanej dotąd jako standard stosowany $\mathrm{w}$ analizie podejmowanych decyzji. $\mathrm{O}$ ile funkcja użyteczności majątku była wklęsła dla osób niechętnych ryzyku, a wypukła dla osób lubiących ryzykować to nowa funkcja przypisywała zyskom i stratom postrzegalną wartość (Bogdanowicz, 2014, s. 26). Funkcja wartości 
jest funkcją rosnącą i wklęsłą w obszarze zysku oraz rosnącą i wypukłą $w$ obszarze strat (Kahneman i Tversky, 1986, pp. 253-260). Potwierdzenie istotności teorii ekonomii behawioralnej nastąpiło w 2017 roku, kiedy to Nagrodę Banku Szwecji im. Alfreda Nobla $w$ ponownie przyznano za zasługi właśnie $w$ ekonomii behawioralnej. Otrzymał ja R. Thaler, który wspólnie z C.R. Sunsteinem wskazali, że człowiek nie jest w stanie zachowywać się racjonalnie i podejmuje decyzje, które często są nie w jego własnym interesie.

\subsection{Ekonomia behawioralna: założenia}

Ekonomia behawioralna, stanowiąca jeden $z$ najświeższych nurtów w ekonomii, staje się dziś nurtem szybko rozwijającym się. Świadczyć o tym może bardzo duża liczba badań empirycznych i eksperymentów przeprowadzanych w jej zakresie (Zalega, 2015, s. 8). Korzenie nurtu behawioralnego $\mathrm{w}$ ekonomii sięgają samego behawioryzmu (pojęcia z podłoża nauk psychologicznych). Koncentruje się on na zachowaniach człowieka i bodźcach, jakie wpływają na jego zachowania, a pochodzą $z$ otaczającego go środowiska. Sam behawioryzm zakłada, że kluczem do zrozumienia zachowań jednostek jest zrozumienie zależności, które zachodzą między bodźcem oddziałującym na człowieka a jego reakcją na działanie tego bodźca (Strelau, 2003, s. 42). Idąc więc dalej tym tokiem rozumowania, behawioryzm oparty jest więc na założeniu, że nie ma znaczenia czy człowiek podejmuje działania, które można obserwować z możliwością przewidywania ich konsekwencji, czy też są to nieobserwowalne myśli lub emocje. Wszystko to jest traktowane jako „zachowanie” i nie wymaga zastanawiania się nad tym, co przy okazji owych „zachowań” dzieje się w umyśle człowieka (Zalega, 2015, s. 8).

Wpływ założeń zaczerpniętych $z$ nauk psychologicznych na ekonomię sprawił, że do nauk ekonomicznych podchodzi się z większą interdyscyplinarnością. Początki związków ekonomii z psychologią pojawiają się już w starożytności, a ich podstawą staje się dzieło Kse- nofonta zatytułowane Oikonomikos (Makuch, 2012, s. 126).

Istotny wkład w połączenie aspektów psychologicznych $z$ ekonomicznymi wniósł do nauki J. Bentham, współczesny A. Smithowi. Był on twórcą terminu homo oeconomicus. Ujmował on w ten sposób człowieka, który podejmując w sposób racjonalny decyzje ekonomiczne, zawsze ma na względzie własny interes.

Już w końcu XIX wieku dwóch ekonomistów neoklasycznych - F.Y. Edgeworth oraz W.S. Jevons włączyło do swoich badań ekonomicznych założenia proponowane przez niemieckich psychologów (Polowczyk, 2009, s. 3). Późniejsze próby odłączenia aspektów psychologicznych $z$ nauk ekonomicznych nie przyniosło pożądanych rezultatów, a naukowcy zajmujący się badaniami ekonomicznymi w dalszym ciągu kontynuowali włączanie aspektów psychologicznych w ich badania.

Ekonomia behawioralna, czerpiąc $z$ nauk psychologicznych, stała się młodą i szybko postępującą dziedziną. W wynikach wielu badań przeprowadzonych na gruncie ekonomii behawioralnej (poprzez doświadczenia i obserwacje) opisywano zachowania, które stanowią odchylenia od tego, co określane jest w ekonomii racjonalnością (Polowczyk, 2010, s. 1). Odchylenia te, określane są mianem błędów poznawczych (cognitive bias). W tym kontekście, ekonomia behawioralna wprowadza nowy sposób określania zachodzących zjawisk $z$ wykorzystaniem doświadczenia, jakie $\mathrm{w}$ badaniach mają nauki psychologiczne (Makuch, 2012, s. 129). Wzbogacenie nauk ekonomicznych o doświadczenia psychologiczne, pozwoliło na inne ujęcie człowieka rozumnego, ale podatnego licznym skłonnościom, które rzutują na dokonywane przez niego wybory i podejmowane decyzje. Do najczęściej wskazywanych, nieuświadomionych skłonności należą m.in.: wszelkiego rodzaju zniekształcenia $\mathrm{w}$ postrzeganiu oraz rozumieniu otaczającej rzeczywistości ( $w$ tym również pieniędzy oraz kosztów), zbyt wysoki poziom pewności siebie, obawy przed sytuacjami które są nieznane, podatność na emocje oraz wpływ otoczenia (Polowczyk, 2009, s. 5). Czynniki te stały się 
kluczowe do podjęcia badań dotyczących procesów decyzyjnych u konsumentów. Wskazują one, jak wiele aspektów wpływa na decyzje, które każdego dnia podejmują konsumenci. Znając te zasady, można więc celowo stymulować procesy decyzyjne tak, aby były one korzystne dla sprzedających.

\section{Materiały i metody}

W niniejszym artykule zastosowano kilka metod badawczych. Pierwszą $z$ nich jest analiza literatury oraz wyników przeprowadzonych już badań w zakresie zachowań konsumentów. Wykorzystano literaturę $\mathrm{w}$ zakresie ekonomii behawioralnej, psychologii, marketingu oraz zachowań konsumenckich. Ponadto, wykorzystano obserwację własną autora dotyczącą zachowań konsumentów, którzy dokonują zakupów produktów oraz usług.

\section{Wyniki badania}

Jak wskazano, niezwykle kluczową rolę w procesie decyzyjnym wśród konsumentów odgrywają czynniki psychologiczne. Czynniki te wpływają również na potrzeby konsumentów. Te są $z$ reguly zmienne $w$ czasie, a przedsiębiorcy, którzy mają ich świadomość sami, w sposób kontrolowany, mogą kreować potrzeby konsumenckie. Zwrócenie uwagi na ograniczoną racjonalność konsumentów w podejmowaniu decyzji oraz czynniki emocjonalne warunkujące wybory sprawiają, że można dokonywać obserwacji i analizy zachowań konsumentów. Obecnie, bardzo intensywnie rozwija się neuromarketning, mogący stanowić wsparcie dla przedsiębiorstw $\mathrm{w}$ kreowaniu potrzeb. Aktualnie intensywnym procesom badawczym poddaje się sferę wpływu mózgu na zachowania konsumentów (Gazzaniga, 2013, s. 82). W tym przypadku, kluczowym zagadnieniem jest kwestia wpływu wolnej woli na decyzje podejmowane przez konsumentów.

$Z$ pomocą $w$ badaniu wpływu mózgu na decyzje konsumenckie przychodzi równiez medycyna. Obecnie, technologia umożliwia przeprowadzenie badań reakcji mózgu na różnorodne bodźce (np. elektroencefalografia, EEG), dzięki którym można sprawdzić, w jaki sposób oddziaływanie konkretnych bodźców wpływa na działanie konsumenta (Mruk, 2017, s. 85). Intensywnie również rozwijane są badania eye-trackingu, który pozwala na ocenę ruchu gałek ocznych człowieka i sposobu postrzegania, np. rozmieszczenia towarów, ich układowi, kolorom, itp. (Mruk, 2017, s. 85).

Obecnie, obserwacje konsumentów prowadzone są $\mathrm{w}$ ujęciu interdyscyplinarnym. Spojrzenie na konsumenta i jego decyzje z perspektywy wielu nauk, pozwala na poznanie jego natury i sposobów funkcjonowania.

Coraz mocniej uwydatnia się potrzeba skierowania uwagi na aspekty poza cenowe, w tym psychologiczne, które mogą wpłynąć na dokonany wybór i użyteczność danego dobra.

W przypadku wyborów dokonywanych przez konsumentów, głównym czynnikiem mogą stać się emocje. W tym przypadku, niezwykle istotne jest zwrócenie uwagi na klientów działających pod wpływem aktywizacji odpowiednich bodźców. W związku z tym, $\dot{z}$ istnieje silne połączenie $\mathrm{w}$ relacji bodziec-reakcja (zachowanie), można łatwo oddziaływać na klientów. Przykładowo, emitując odpowiedni rodzaj muzyki, sprzedający mogą stymulować wzrost zakupów odpowiedniego produktu (Cialdini, 2017, s. 59). Warto zwrócić uwagę, że klienci chętniej sięgają po produkty, które są większe (lub w większym opakowaniu), jaśniejsze, nietypowe lub przykuwające uwage poprzez ruch (Mruk, 2017 , s. 87). Ta sama gramatura produktu, wyeksponowana w opakowaniu wąskim oraz wysokim będzie chętniej nabywana niż ta sama gramatura $\mathrm{w}$ opakowaniu szerokim. W tym przypadku, sprzedający bardzo mocno oddziałują na funkcjonowanie zmysłu wzroku oraz postrzeganie. Producenci prześcigają się nieustannie w przygotowaniu opakowań, które będą dostarczać więcej satysfakcji z nabytego dobra konsumentom, choć ich zawartość jest taka sama.

Innym zabiegiem podejmowanym przez sprzedawców mającym na celu ułatwienie wy- 
boru konsumentom, jest lokacja produktów w sklepie. Produkty zamieszczone na wysokości wzroku nabywców są chętniej kupowane. Umieszczając produkt droższy obok tańszego, sprzedawcy mogą doprowadzić do tego, że kupujący chętniej będą sięgać po produkt tańszy i zostanie on $\mathrm{w}$ konsekwencji sprzedany w większej ilości (Borusiak i in., 2017).

Według obserwacji poczynionych przez M. Gazzaniga (2013, s. 56), mózg ludzki podejmuje decyzję już 11 minut wcześniej przed jej uświadomieniem. Wielu konsumentów podejmuje decyzje zakupowe pod wpływem ogłaszanych przez sprzedających promocji oraz rabatów. Warto zwrócić szczególną uwagę na to, w jaki sposób prezentowane są promocyjne ceny. Zwykle jest to kolor jaskrawy, z łatwością oddziałujący na zmysł wzroku. Pojawia się tu problem postrzegania przez ludzki umysł znaczenia promocji, a dokładniej determinowanej przez nią ceny produktu. Wystarczy zaobserwować zależność, że jeśli wśród produktów będą dwa o podobnej funkcjonalności, a jeden $z$ nich będzie kosztował 53 PLN, a drugi 62 PLN, to konsumenci zdecydują się na pierwszy z produktów. Jeśli dołożony zostanie na półce obok trzeci produkt o cenie najwyższej (np. 80 PLN) wówczas klienci najczęściej wybierają produkt $z$ ceną 62 PLN. Obserwacja ta zdaje się potwierdzać wprowadzone przez D. Ariely'ego (2018 s. 133) pojęcie „wabiku” w odniesieniu do cen. Kwestia ceny przy sprzedaży produktów odgrywa kluczową role, nie tylko w znaczeniu wydatku, który konsument ma ponieść, ale również jej prezentacja może wpłynąć na podejmowanie decyzji przez konsumentów. Przy relatywnie niskich cenach jednostkowych za produkt, obniżka ceny, np. o 4 PLN jest zdecydowanie szybciej zauważana przez konsumentów niż w przypadku cen wyższych. Obniżenie ceny kostki masła z 8 PLN do 4 PLN sprawia, że klienci chętniej ten produkt nabywają niż w przypadku trunku, którego cena ze 120 PLN została obniżona do 116 PLN. Wartościowo, cena została obniżona o 4 PLN. Jednak umysł człowieka odczytuje taką zmianę zupełnie inaczej. Warto w tym miejscu również przywołać koncepcję użyteczno- ści transakcyjnej R. Thalera. Uważał on, że jest ona ściśle związana z użytecznością konsumpcji. Według tej koncepcji, konsument posiada jakieś wyobrażenie dotyczące ceny produktu w określonych okolicznościach. Pojawiające się wyraźne odchylenia od kwoty, którą założył konsument, sprawiają, że odbiera on dany koszt jako okazję.

Wielu konsumentów deklaruje, że nabywając produkty czy korzystając $z$ różnych usług kwestią kluczową jest cena. Przytoczone przykłady, zaczerpnięte $z$ własnych obserwacji zachowań konsumentów, zdają się przeczyć wspomnianym deklaracjom konsumenckim.

Warto podkreślić, że konsumenci podejmują decyzje często jeszcze przed udaniem się do konkretnego sprzedawcy. Dowodzić temu mogą badania, które zostały przeprowadzone w 2006 roku przez Centrum Badania Opinii Społecznej (CBOS) na grupie ponad 3,3 tysiąca uczniów ostatnich klas szkoły gimnazjalnej oraz podstawowej. Z wyników badań można wnioskować, że ponad połowa ankietowanych podejmowała decyzje przed wizytą w sklepie (Zięba, 2010, s. 274). Z całą pewnością dynamiczny rozwój technologii wpływa na fakt, że wiele decyzji podejmowanych jest przez konsumentów już dużo wcześniej niż w samym momencie zakupu.

Decyzje konsumenckie, szczególnie w przypadku młodych konsumentów, podejmowane mogą być również pod wpływem presji otoczenia, które dziś stanowi zdecydowany ośrodek kreowania potrzeb konsumenckich. Wielu konsumentów ulega często presji nabywczej i kieruje się nią bardziej niż zdrowym rozsądkiem. Za kreatora potrzeb nabywczych uważa się dziś również wszelkie działania marketingowe. Choć wielu konsumentów deklaruje świadomość, że nie wszystkie informacje są prawdziwe, to $w$ przypadku młodych konsumentów aż $70 \%$ z badanych przyznało, że nie weryfikowało prawdziwości działań marketingowych (Zięba, 2010, s. 277).

Przedstawione wyniki badań oraz obserwacji własnych, poczynionych na konsumentach świadczą o tym, że obecnie istnieje istotny wpływ czynników psychologicznych i emocjonalnych na zachowania konsumenckie. 


\section{Zakończenie}

Ekonomia behawioralna to dziedzina stosunkowo nowa, która u swoich podstaw była traktowana $z$ ogromnym sceptycyzmem w stosunku do klasycznych nurtów, proponowanych przez ekonomistów na przestrzeni kolejnych lat. Stanowi ona nowy sposób określania zjawisk ekonomicznych, korzystając $z$ doświadczeń, jakie niosą ze sobą nauki psychologiczne. Szczególne powiązania $z$ naukami psychologicznymi a ekonomią, można dostrzec w głównych kierunkach ekonomii behawioralnej. Na jej gruncie powstała ekonomia psychologiczna, której podstawę stanowią założenia psychologii kognitywnej. Jej przedmiotem są procesy psychiczne leżące u podstaw decyzji konsumentów. Korzystając z nauk psychologicznych, identyfikowane są czynniki wpływające na zachowania konsumentów oraz analizowane konsekwencje podejmowanych decyzji. Kolejny z kierunków ekonomii behawioralnej obejmuje swoim zakresem finanse. Stosujac modele matematyczne oraz metody ilościowe, można dokonać badania racjonalność zachowań uczestników rynków finansowych. Korzystając z elementów wypracowanych na gruncie ekonomii behawioralnej, można również zauważyć ukierunkowaną w ten sam sposób makroekonomię. Wykazuje ona duży charakter interdyscyplinarny i nie bazuje na modelach matematycznych. Wyjaśnia ona różnice zachodzące między realną ekonomią a modelem równowagi ogólnej (Polowczyk, 2010, ss. 4-5).

Zerwanie $z$ elementami ekonomii neoklasycznej oraz wprowadzenie elementów psychologicznych sprawiło, że głębszej analizie można poddać zachowania konsumentów. Znajomość tych zachować może wpływać w sposób stymulujący na kształtowanie się poszczególnych sektorów gospodarki, w tym sektora usług (który świadczy o dynamice rozwoju gospodarczego). Ekonomia behawioralna pozwala więc ujmować człowieka i jego decyzje od strony zachowań i wskazuje na to, jak wiele czynników wpływa na decyzje konsumentów i ich zachowania, które są stymulowane poprzez odpowiednie działa- nia. Rozwój badań nad tą gałęzią ekonomii z pewnością może przyczynić się do efektywności oraz umocnienia konkurencji rynku, a w konsekwencji wpłynąć na poziom rozwoju gospodarczego.

\section{Bibliografia}

Ariely, D. (2018). Potęga irracjonalności: ukryte sity, które wptywaja na nasze decyzje. Sopot: Smak Słowa.

Bogdanowicz, B. (2014). Ekonomia behawioralna a klasyczny paradygmat ekonomii. Folia Pomeranae Universitas Technologiae Stetinensis. Oeconomica, 313(76).

Borusiak, B., Pierański, B., i Strykowski, S. (2017). Percepcja ekspozycji towarów w sklepie. Studia Ekonomiczne. Zeszyty Naukowe Uniwersytetu Ekonomicznego w Katowicach, 334.

Camerer, C. (2006). Behavioral economics. W: R. Blundell, W. Newey, i T. Persson (red.), Advances in economics and econometrics: theory and applications. Ninth world congress. Cambridge: Cambridge University Press. doi:10.1017/CBO9781139052276.009.

Cialdini, R. (2017). Pre-swazja: jak w petni wykorzystać techniki wpływu społecznego? Gdańsk: Gdańskie Wydawnictwo Psychologiczne.

Clark, J.M. (1918). Economics and modern psychology. Journal of Political Economy, 26 (1).

Friedman, M. (1953). Essays in positive economics. Chicago: University of Chicago Press.

Gazzaniga, M. (2013). Kto tu rządzi: ja czy mój mózg? Sopot: Smak Słowa.

Kahneman, D., i Tversky, A. (1986). Rational choice and the framing of decisions. The Journal of Bussines, 59(S4). doi:10.1086/296365.

Makuch, M.A. (2012). Decyzje podmiotów gospodarczych w ujęciu ekonomii behawioralnej. Studia i Prace Wydziału Nauk Ekonomicznych i Zarządzania Uniwersytetu Szczecińskiego, 27.

Marshall, A. (2013). Principles of economics. Basingstoke: Palgrave Macmillan. doi:10.1057/9781137375261.

Mruk, H. (2017). Zachowania konsumentów w świetle ekonomii behawioralnej. Studia Ekonomiczne. Zeszyty Naukowe Uniwersytetu Ekonomicznego $w$ Katowicach, 312.

Polowczyk, J. (2009). Podstawy ekonomii behawioralnej. Przeglad Organizacji, 12.

Polowczyk, J. (2010). Elementy ekonomii behawioralnej w dziełach Adama Smitha. Ekonomista, 4.

Próchnicki, L. (2006). Z dziejów myśli ekonomicznej. Warszawa: Infoplan. 
Simon, H. (1986). Models of bounded rationality. Cambridge: MIT Press.

Sołek, A. (2010). Ekonomia behawioralna a ekonomia klasyczna. Zeszyty Naukowe PTE, 8.

Strelau, J. (2003). Psychologia: podręcznik akademicki. Gdańsk: Gdańskie Wydawnictwo Psychologiczne.

Zalega, T. (2015). Ekonomia behawioralna jako nowy nurt ekonomii: zarys problematyki. Studia i Materiaty Wydziatu Zarządzania Uniwersytetu Warszawskiego, 1. doi:10.7172/1733-9758.2015.18.1.

Zięba, K. (2010). Czynniki kształtujące zachowania nabywcze młodych konsumentów. Ekonomiczne Problemy Ustug, 54.
Zygan, M. (2013). Ekonomia behawioralna: wprowadzenie do problematyki. Studia i Prace Wydziału Nauk Ekonomicznych i Zarządzania Uniwersytetu Szczecinskiego, 32.

Informacje uzupełniające

Wkład autorski: autor zaakceptował ostateczną wersję artykułu.

Źródła finansowania: artykuł został w całości sfinansowany ze środków własnych autora.

Consumer decisions and behavior economy assumptions

\begin{abstract}
Motivation: Psychological aspects are a key element of choices made by consumers. Thus, Behavioral economics becomes one of the fastest-growing trends in contemporary economics.

Aim: The aim of the review article is to identify the most important relationships that exist between economics and psychology and to point the key assumptions to understand consumer choices made on the market.

Materials and methods: A method of critical analysis of the subject literature and observation of consumer behavior was used.

Results: The conducted analysis indicates the existence of multifaceted factors that may influence consumer decisions and have consequences for households and their members.
\end{abstract}

Keywords: behavioral economics; consumer choice theory; psychology; marketing activities JEL: B21; D11; M31 